\title{
Seasonal Variation of Anti-oxidant and Anti-bacterial Activities in Acer palmatum Extract
}

Young Whan Sung ${ }^{1}$, Min Ju Chang ${ }^{1}$, Yong-Keun Choi ${ }^{1}$, Hakjin Song ${ }^{1}$, Sok Young Shim ${ }^{1}$, Jae-Yoon Yoon ${ }^{1}$, Kwang Jin Kim ${ }^{2}$, Hyung Joo Kim ${ }^{1 *}$

${ }^{1}$ Department of Biological Engineering, Konkuk University, Seoul, Korea

${ }^{2}$ Urban Agriculture Research Division, National Institute of Horticultural and Herbal Science, Rural Development Administration, Wanju-gun, Jeollabuk-do, Korea

"Corresponding author: Hyung Joo Kim, Department of Biological Engineering, Konkuk University, 120 Neungdong-ro, Gwangjin-gu, Seoul 05029, Korea

Tel.: +82 220496111

Fax: +82 24462677

Email: hyungkim@konkuk.ac.kr

This work is part of the Young Whan Sung's Ph.D. thesis at the Konkuk University,

Seoul, Korea.

Received October 11, 2016

Revised November 30, 2016

Accepted December 9, 2016

Published December 30, 2019

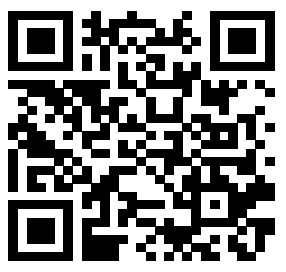

\begin{abstract}
Purpose: This study aimed to investigate the optimal collection time of Acer palmatum extract (APE) through anti-oxidant and anti-bacterial activities. Methods: We confirmed the anti-oxidant activity of APE by estimating the total polyphenol content, total flavonoid content, 2,2-diphenyl-1-picrylhydrazyl (DPPH) radical scavenging effect, and cell viability. In addition, we determined anti-bacterial activities against Staphylococcus aureus, Bacillus subtilis, and Pseudomonas aeruginosa during growth. Results: Anti-oxidant activities of APE peaked in July and November. RAW 264.7 displayed high cell viability in APE concentrations of 5-100 $\mu \mathrm{g} / \mathrm{mL}$ in July and November. As a result of conducting anti-bacterial activities, seasonal variation of APE against three bacteria was exhibited. Conclusion: The anti-oxidant and anti-bacterial activities of APE showed seasonal variation, and high cell viability in July and November; therefore, consideration of the optimal seasonal collection time for Acer palmatum could be an important factor attributing to its natural antioxidant properties and the optimal collection time was confirmed especially to be in July and November.
\end{abstract}

Keywords: Acer palmatum, Anti-oxidant activity, Anti-bacterial activity, Cytotoxicity, Seasonal variation

\section{Introduction}

최근에 자연지향적이고 환경친화적인 소비형태와 함께 합성 항 산화제의 독성이 보고되면서 화장품 산업에서도 천연유래 물질을 이용하여 항산화, 항균, 항알러지, 항염, 그리고 항노화 등의 생리 활성을 가진 화장품 소재 개발이 활발히 이루어지고 있다(Park, 2005).

피부에는 활성산소종의 생성을 촉진하는 불포화지방 산이 풍부하고 자외선에 의해 생성된 활성산소가 matrix metalloproteinase (MMP)의 발현을 유도하여, 진피층의 collagen, elastin, glycosaminoglycan의 사슬을 절단시켜서 피 부 주름을 생성시키고, 또한 피부 내 세포의 DNA 손상은 염증 과 정과 알러지 반응에 관여하여 아토피 피부염과 여드름, 건선, 피
부암 등의 피부질환과 피부노화를 유발한다(Kim et al., 2016).

식물은 외부자극 및 광합성 과정에서 발생되는 활성산소종 에 의한 산화적 손상으로부터 보호할 수 있는 폴리페놀 화합물인 flavonoid, anthocyanin, tannin, catechin 등의 산화방지 물질 을 다량 함유하고 있어 산화적 스트레스를 유발하는 자유라디칼의 생성을 지연시키거나 활성을 억제하는 것으로 알려져 있다(Pyo et al., 2004).

단풍나무는 단풍나무과(Aceraceae)에 속하는 활엽수종으로, 학 명은 Acer palmatum Thunb.이다. 단풍나무속에는 약 150종이 우리나라를 비롯한 동아시아와 북미, 유럽 등의 북반구 온대지역 에 분포하고 있다(Lim, 1997). 단풍나무에서 채취된 수액은 천연 감미료로 이용되는데, 수액(樹液)의 주성분은 자당이고, 이외에도 카르복실산, 페놀, 페닐배당체, 올리고당, 바닐린, 아미노산을 포 
함한다(Ball, 2007). 단풍나무는 중국과 일본, 우리나라에서 약용 식물로 사용하며 류머티즘, 타박상, 안과질환, 통증, 해독 등 다 양한 질환치료에 효과적인 것으로 알려져 있다. 34 개 단풍나무속 에서 flavonoids (18.7\%), tannins (12.4\%), diarylheptanoids (8.8\%), phenylpropanoids (22.4\%), phytosterols $(9.7 \%)$ 등의 331 개의 생리활성 물질이 확인되었으며, 전체 화합물의 5 분의 1 에 해당하는 플라보노이드가 함유되어 있는 것으로 보고되었다 (Aritomi, 1963; Bi et al, , 2016).

현재까지 진행된 단풍나무속에 관한 선행 연구로는 항산화 활 성(Schmitzer et al., 2009; Prihantini et al., 2014), 항균 활 성(Webb \& Agnihotri, 1970), 항염 효과(Ding et al., 2010), 항 암 효과(González-Sarrias et al., 2012) 등에 대하여 보고된 바 있으나, 수확시기별 단풍나무의 항산화 활성과 항균 활성을 비교 한 연구는 미비한 실정이다. 식물의 생리활성 물질은 구조와 특성 이 매우 다양하고 여러 가지 조건에서 생리활성 물질의 함량이 다 르므로 수확시기별 생리활성 물질의 함량을 조사하는 것은 어려 운 일이다. 그러나 최근 식물의 생리활성 성분이 가장 많이 함유 되는 시기를 규명하여 약용식물 생산에 이용하고 있다(Oh et al., 2015). 해당화 잎의 시기별 연구에 따르면 11월에 채취한 해당화 의 잎이 9 월에 비해 ascorbic acid 함량이 1.7 배 정도 높았으며 (Kim et al., 2001), 인삼 잎의 총 사포닌 함량이 4월에 비해 5 월 에 8배 가량 증가한 연구 결과(Choi et al., 2009a)가 있다.

따라서 본 연구에서는 단풍나무 추출물의 수확시기에 따른 항 산화 함량과 활성을 측정하고 항균 활성을 비교하여, 항산화능과 항균 활성이 높은 적정 수확시기 및 이용시기를 도출하고자 하였 다. 또한 본 연구가 천연 항산화제로서의 이용가능성 검토에 기초 자료로 활용되기를 기대한다.

\section{Methods}

\section{1. 시료준비}

본 실험에 사용된 단풍나무(Acer palmatum)의 잎은 서울 광진 구 능동로 건국대학교 교내의 단풍나무에서 채취하여 수세한 후 자연 건조시키고 분쇄하였다. 단풍나무는 낙엽활엽 교목으로 잎 이 핀 4 월부터 낙엽이 되기 전 11 월까지를 사용하였다. 건조 시 료 $2 \mathrm{~g}$ 에 $70 \%$ 에탄올을 10 배 가해 $60^{\circ} \mathrm{C}, 3 \mathrm{~h}$ 동안 water bath (SB-1200; EYELA, Japan)에서 추출하였다. 원심분리기(VS4000i; Vision Scientific, Korea)를 이용하여 3500 rpm, 15 $\min$ 동안 추출물을 원심분리한 후, 여과지(Whatman No.2; GE Healthcare Life Sciences, USA)로 상층액을 여과하고, 감압농 축기(N-1110; EYELA)를 사용하여 에탄올을 제거한 후, 동결 건 조하여 분말형태의 추출물(Acer palmatum extract, $\mathrm{APE}$ )을 사 용하였다.

\section{2. 실험시약}

본 연구에 사용된 시약 ethanol, Folin \& Ciocalteu's phenol reagent, sodium carbonate $\left(\mathrm{Na}_{2} \mathrm{CO}_{3}\right)$, gallic acid, potassium acetate, aluminium nitrate, quercetin, 1,1-diphenyl2-picrylhydrazyl (DPPH), methanol, ascorbic acid, penicillin, streptomycin, neutral red solution (NR solution), formaldehyde, phosphate buffered saline (PBS), NR desorb solution은 Sigma-Aldrich (USA)를 사용하였고, high glucose Dulbecco's modified Eagle's medium (DMEM)과 fetal bovine serum (FBS)는 Thermo Scientific (USA)를 사용하였다.

\section{3. 항산화 측정}

1) 총 폴리페놀 함량

총 폴리페놀 함량은 Folin-Ciocalteu method (Singleton \& Rossi, 1965)를 수정하여 Folin-Ciocalteu's phenol reagent가 시료의 페놀성 화합물에 의해 환원되어, 몰리브덴 청색으로 발색 되는 원리를 이용하여 정량하였다. 증류수 용액에 시기별 $\mathrm{APE}$ 를 $1 \mathrm{mg} / \mathrm{mL}$ 농도로 희석한 후, APE $100 \mu \mathrm{L}$ 와 Folin-Ciocalteu's phenol reagent $750 \mu \mathrm{L}$ 을 혼합하여 $5 \mathrm{~min}$ 동안 반응시킨 뒤, 1 $\mathrm{M} \mathrm{Na}_{2} \mathrm{CO}_{3}$ 를 $750 \mu \mathrm{L}$ 를 혼합하여 암실에서 $60 \mathrm{~min}$ 동안 반응시 킨 후 $765 \mathrm{~nm}$ 에서 UV spectrophotometer (Optizen $2120 \mathrm{UV}$; Mecasys, Korea)를 사용하여 흡광도를 측정하였다. 이때 gallic $\mathrm{acid}$ 를 표준물질로 사용하여 0-100 $\mu \mathrm{g} / \mathrm{mL}$ 농도로 제조한 검량 곡선을 작성하고 이로부터 총 폴리페놀 함량을 구하였다.

\section{2) 총 플라보노이드 함량}

총 플라보노이드 함량 측정은 Moreno et al. (2000)의 방법을 이용하였다. 증류수 용액에 시기별 $\mathrm{APE}$ 를 $1 \mathrm{mg} / \mathrm{mL}$ 농도로 희 석한 후, $\mathrm{APE} 100 \mu \mathrm{L}$ 와 $1 \mathrm{M}$ potassium acetate $20 \mu \mathrm{L}$ 를 혼합 하여 $40 \mathrm{~min}$ 방치한 후 10\% aluminium nitrate $20 \mu \mathrm{L}$ 와 80\% ethanol $860 \mu \mathrm{L}$ 를 혼합하여 실온에서 $40 \mathrm{~min}$ 동안 방치한 후 UV spectrophotometer 를 이용하여 $415 \mathrm{~nm}$ 에서 흡광도를 측정 하였다. 이때 총 플라보노이드 함량은 quercetin을 표준물질로 사 용하여 0-100 $\mu \mathrm{g} / \mathrm{mL}$ 농도로 제조한 검량 곡선을 작성하고 이로 부터 총 플라보노이드 함량을 구하였다.

\section{3) DPPH radical 소거활성}

$\mathrm{APE}$ 의 산화방지 활성을 측정하기 위하여 $\mathrm{DPPH}$ 를 사용한 Blois (1958)의 방법을 응용하여 측정하였다. 각 시료의 DPPH 에 대한 전자공여 효과로써 시료의 환원력을 측정하였다. 메탄올 용액에 녹인 $0.2 \mathrm{mM} \mathrm{DPPH} \mathrm{용액} 800 \mu \mathrm{L}$ 와 시기별로 메탄올 용 액에 녹인 APE $200 \mu \mathrm{L}$ 를 혼합하여 최종 농도 $125 \mu \mathrm{g} / \mathrm{mL}$ 가 되 도록 희석한 후, 암실에서 $20 \mathrm{~min}$ 동안 반응시키고 microplate reader (Synergy-HT; BioTek Instruments, USA)를 이용하여 
$517 \mathrm{~nm}$ 에서 흡광도를 측정하였다. DPPH radical 소거활성은 아 래의 식에 의해 계산하여 산출하였으며, 양성대조군은 ascorbic acid를 사용하여 활성을 비교하였다. 또한 APE와 ascorbic acid 의 농도별 $\mathrm{DPPH}$ radical 소거활성을 확인하기 위해, 위와 동일한 방법으로 메탄올 용액에 녹인 $0.2 \mathrm{mM} \mathrm{DPPH}$ 용액 $800 \mu \mathrm{L}$ 와 메 탄올 용액에 녹인 시료(APE 및 ascorbic acid) $200 \mu \mathrm{L}$ 를 혼합하 여 최종 농도 $10,50,100,1000 \mu \mathrm{g} / \mathrm{mL}$ 가 되도록 희석한 후, 암 실에서 $20 \mathrm{~min}$ 동안 반응시켜 $517 \mathrm{~nm}$ 에서 흡광도를 측정하였다.

$\mathrm{DPPH}$ radical 소거활성 $(\%)=100-($ 시료 첨가군의 흡광도 $) /($ 시 료 무첨가군의 흡광도 $) \times 100$

\section{4. 세포배양}

실험에 사용한 세포주 RAW 264.7은 한국세포주은행(Korea) 에서 분양하여 사용하였고, 배양 시에는 DMEM에 사용하였으며, $10 \% \mathrm{FBS}$ 와 $1 \%$ penicillin (100 IU/mL), 1\% streptomycin (50 $\mu \mathrm{g} / \mathrm{mL}$ )을 첨가하여 $37^{\circ} \mathrm{C}$ 로 유지되는 $5 \% \mathrm{CO}_{2}$ 습윤 배양기에서 배양하였다.

\section{Neutral red assay를 이용한 세포독성 측정}

실험에서 사용된 시료의 독성 농도 범위를 알아보기 위하 여 neutral red assay (NR assay)를 이용하여 측정하였다 (Borenfreund \& Puerner, 1985). 세포주는 RAW 264.7 세포를 사용하였으며, 96 well plate에 $3 \times 10^{4} \mathrm{cells} / \mathrm{well}$ 의 농도로 분주 하여 $24 \mathrm{~h}$ 동안 $37^{\circ} \mathrm{C}, 5 \% \mathrm{CO}_{2}$ 배양기에서 부착시켰다. 세포 부 착 확인 후 $\mathrm{APE}$ 를 $\mathrm{DMEM}$ 배지에 녹여 $5,10,25,50,100 \mu \mathrm{g} /$ $\mathrm{mL}$ 농도가 되도록 첨가하여 $48 \mathrm{~h}$ 배양하였다. 배양한 세포는 배 양액을 NR solution이 $1 \%$ 포함된 무혈청 배지로 교환하여 $3 \mathrm{~h}$ 배양한 다음, 현미경으로 관찰하여 NR의 결정화 유무를 확인하 였다. 세포고정액으로 formaldehyde 용액 $10 \%$ 가 첨가된 $\mathrm{PBS}$ 를 각 well에 $100 \mu \mathrm{L}$ 로 $20 \mathrm{~min}$ 처리하여 고정하였다. NR desorb solution (1\% glacial acetic acid, 49\% ethanol, 50\% distilled water)을 각 well에 $100 \mu \mathrm{L}$ 씩 분주하여 세포내의 NR을 추출하고 microplate reader를 이용하여 $540 \mathrm{~nm}$ 에서 흡광도를 측정하였 고, 세포 생존율은 다음의 식에 따라 계산하였다. 세포 독성 실험 은 동일한 조건하에 독립적으로 3 회 반복 실시하여 평균士표준편 차(mean \pm standard deviation)로 표기하였다.

세포생존율 $(\%)=($ 시료 첨가군의 흡광도 $) /($ 시료 무첨가군의 흡광 도) $\times 100$

\section{6. 항균실험}

항균실험의 실험방법은 다음과 같다. 그람 양성균인 Staphylococcus aureus (S. aureus, 6538 ${ }^{\mathrm{TM}}$; ATCC, USA), Bacillus subtilis (B. subtilis, 19659 ${ }^{\mathrm{TM}}$; ATCC), 그리고 그람 음성균 Pseudomonas aeruginosa (P. aeruginosa, 29336 ${ }^{\mathrm{TM}}$;

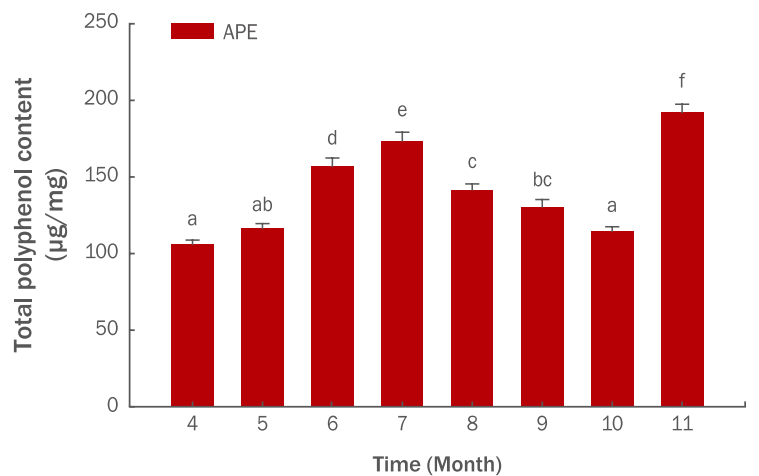

Figure 1. Seasonal variation of total polyphenol content in APE. Polyphenol content in Acer palmatum extract (APE) appeared to peak in November. The results are expressed as mean \pm standard deviation from three independent experiments. The calibration curve of gallic acid $(0-100 \mu \mathrm{g} / \mathrm{mL})$ as a standard material is $y=0.006902 x+0.070775, R^{2}=0.971$. Different letters $\left({ }^{a-f}\right)$ indicate significant difference $(p<0.05)$. APE, Acer palmatum extract.

ATCC)을 액체배지(nutrient broth; Difco, Becton, Dickinson and Company, $\mathrm{USA}$ )에 접종하고 $30^{\circ} \mathrm{C}$ 에서 $24 \mathrm{~h}$ 동안 배양시킨 후 시험에 사용하였으며, $\mathrm{APE}$ 는 메탄올을 이용하여 700, 1000 $\mu \mathrm{g} / \mathrm{mL}$ 농도로 제조하여 사용하였다. S. aureus와 B. subtilis, 그리고 P. aeruginosa 각각의 배양액을 Muller Hinton agar 평 판배지(Difco)에 멸균된 면봉으로 고르게 도말하였다. 멸균된 paper disk $(6.0 \mathrm{~mm})$ 에 시료 약 $40 \mu \mathrm{L}$ 를 흡수시키고, 메탄올 용 매를 휘발시키기 위해 상온에서 $1 \mathrm{~h}$ 동안 방치한 후, 배지에 올리 고 $30^{\circ} \mathrm{C}$ 에서 $18 \mathrm{~h}$ 동안 배양하여 형성된 clear zone을 확인하였 다. 항균실험의 대조군으로는 메탄올을 사용하였다.

\section{7. 통계처리}

본 연구의 실험은 3 회 반복하여 실시하였고, 결과값은 평균 표준편차(mean \pm standard deviation)로 표기하였다. 통계 프 로그램은 SPSS (SPSS Statistics v. 22; IBM, USA)을 이용하 여 일원배치분산분석(one-way ANOVA test)을 하고, Duncan's multiple range test로 평균간의 다중비교를 실시하였다.

\section{Results and Discussion}

\section{1. 항산화능}

수확시기별 총 폴리페놀 함량은 4월에 $105.94 \pm 2.84 \mu \mathrm{g} / \mathrm{mg}$ 을 나타낸 후 7 월에는 $173.32 \pm 5.67 \mu \mathrm{g} / \mathrm{mg}$ 까지 증가하였다. 8 월 이후 감소하여 10 월에는 $114.54 \pm 2.92 \mu \mathrm{g} / \mathrm{mg}$ 을 나타내다가 11 월에는 $191.86 \pm 5.32 \mu \mathrm{g} / \mathrm{mg}$ 로 다시 증가하였다(Figure 1). 


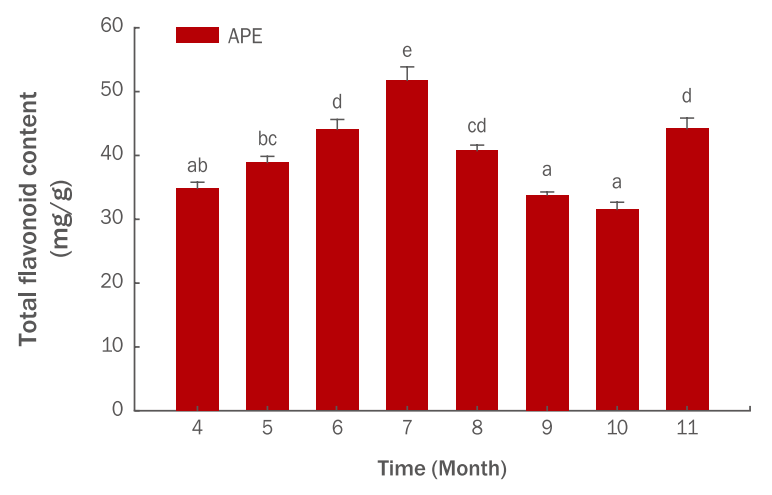

Figure 2. Seasonal variation of total flavonoid content in APE. Total flavonoid content in APE appeared to peak in July. The results are expressed as mean \pm standard deviation from three independent experiments. The calibration curve of quercetin (0$100 \mu \mathrm{g} / \mathrm{mL}$ ) as a standard material is $\mathrm{y}=0.006298 \mathrm{x}+0.004625$, $\mathrm{R}^{2}=0.999$. Different letters $\left({ }^{\mathrm{a}-\mathrm{e}}\right)$ indicate significant difference $(p<0.05)$. APE, Acer palmatum extract.

총 플라보노이드 함량은 4월, 7 월, 10 월, 11 월에 각각 $34.83 \pm$ $0.92,51.71 \pm 2.10,31.50 \pm 1.12,44.15 \pm 1.65 \mu \mathrm{g} / \mathrm{mg}$ 을 나타 내어 총 폴리페놀의 결과와 유사한 경향을 나타내었다(Figure 2). $\mathrm{DPPH}$ radical 소거능은 $125 \mu \mathrm{g} / \mathrm{mL}$ 에서 각각 4월, 7 월, 10 월, 11 월에 $60.76 \%, 79.81 \%, 61.48 \%, 81.46 \%$ 로 나타났다(Figure 3). 총 폴리페놀 함량과 DPPH radical 소거활성이 높은 11월 시 료를 사용하여 대조물질인 ascorbic acid를 사용하여 농도별로 비 교해본 결과, 추출물의 농도가 증가함에 따라 $\mathrm{DPPH}$ radical 소거 능도 증가하는 것을 확인하였다(Figure 4). Kim et al. (2005)의 연구에서는 단풍나무 잎이 $70 \%$ 의 superoxide 소거활성과 $60 \%$ 의 DPPH radical 소거활성을 나타냈으며, Kim et al. (2007)의 제주도 자생식물 탐색에서는 단풍나무 잎이 IC50 $5.44 \mu \mathrm{g} / \mathrm{mL}$ 로 254 종의 식물 가운데 두 번째로 높은 항산화 효과를 보였다. 이러 한 연구결과에 비추어볼 때 단풍나무 추출물이 천연 항산화제로서 활용할 수 있을 것으로 판단된다.

식물은 온도와 강수량 또는 토양적 차이로 동일한 나무라도 수 확시기와 재배지역에 따라 생리활성 성분에 차이가 날 수 있다 (Yim et al., 2016). 참죽나무 잎의 quercitrin 함량의 경우, 7 월과 8월에 각각 $8.89,7.94 \mathrm{mg} / \mathrm{g}$ 으로 최대치를 보이다가 9 월부터 감소하였고(Park \& Kim, 1995), 꾸지뽕나무 열매의 isoflavonoid 화합물은 7월과 8월에 함량이 증가하였다가 9월 에 감소하고 성숙과에서 성분이 증가되어(Yoon et al., 2016) 본 연구와 유사한 경향을 보였다. 또한 Kang et al. (2004)의 감잎 과 뽕잎의 항산화 성분을 수확시기별 조사한 결과, polyphenol, ascorbic acid 및 glutathione의 함량은 잎이 성숙할수록 감소되 었으나, $\beta$-carotene과 $\alpha$-tocopherol의 함량은 잎이 성숙함에 따

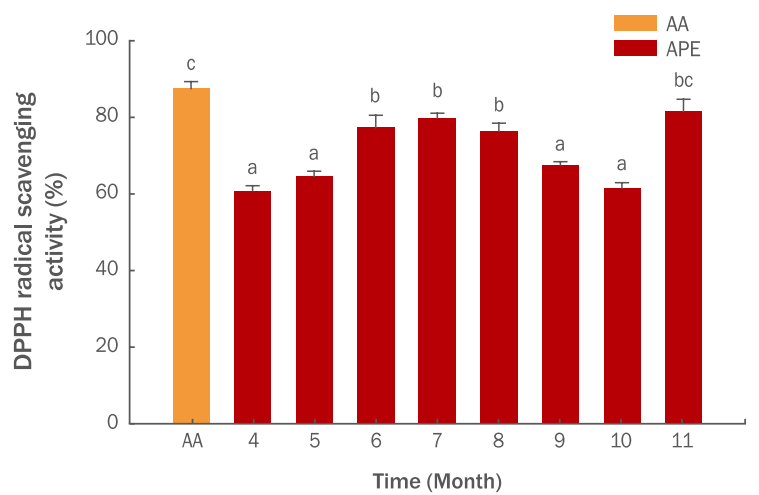

Figure 3. Seasonal variation of DPPH radical scavenging activity in APE.

APE and AA were measured at concentrations of $125 \mu \mathrm{g} / \mathrm{mL}$. AA was used as a positive control. DPPH radical scavenging activity in APE appeared to peak in November. The results were expressed as mean \pm standard deviation from three independent experiments. Different letters $\left({ }^{a-c}\right)$ indicate significant difference $(p<0.05)$. APE, Acer palmatum extract; AA, ascorbic acid; DPPH, 2,2-diphenyl-1-picrylhydrazyl.

라 증가되어 동일 식물이라도 생육 시기에 따라 생리활성 물질의 함량이 다르며 생리활성 성분의 함량이 최고에 달하는 시기도 다 른 것으로 나타났다.

따라서 본 연구 결과에서 단풍나무 추출물의 총 폴리페놀 함량 과 총 플라보노이드 함량이 수확시기에 따라 변화를 나타낸 것은 앞서 제시한 선행연구의 결과들과 상통하는 것이며, 이에 따라 단 풍나무 추출물을 천연 항산화제로써 활용함에 있어, 수확시기는 매우 중요한 요소로 작용할 것임을 알 수 있다.

\section{RAW 264.7 세포에 대한 세포독성}

세포의 증식과 생존율을 확인하기 위하여 항산화 함량과 활성 이 높은 7월과 11월 시료를 선정하여 NR assay를 실시하였다. $\mathrm{RAW} 264.7$ 세포에 대해 $\mathrm{APE}$ 를 $5,10,25,50,100 \mu \mathrm{g} / \mathrm{mL}$ 농 도별로 세포독성을 실험한 결과, 농도 $100 \mu \mathrm{g} / \mathrm{mL}$ 에서 세포생존 도가 7월과 11 월에 각각 $102 \%, 90 \%$ 이상 유지하는 것을 확인할 수 있었다(Figure 5). 선행 연구인 가을철 붉게 물든 단풍나무의 잎에서 분리한 vitexin의 세포독성을 MTT assay로 분석한 결과, $100 \mu \mathrm{g} / \mathrm{mL}$ 농도에서 $85 \%$ 이상의 세포생존율을 보여 농도 $10-$ $100 \mu \mathrm{g} / \mathrm{mL}$ 까지는 세포독성을 유발하지 않는 것을 확인하였다 (Kim et al., 2005). 본 연구에서도 $100 \mu \mathrm{g} / \mathrm{mL}$ 농도까지 RAW 264.7 세포생존율이 $90 \%$ 이상 유지되는 것으로 나타나 APE가 세포생존율에 크게 영향을 주지 않는 것으로 해석된다.

\section{3. 항균실험}

3 가지 균주(S. aureus, B. subtilis, P. aeruginosa)에 대해 


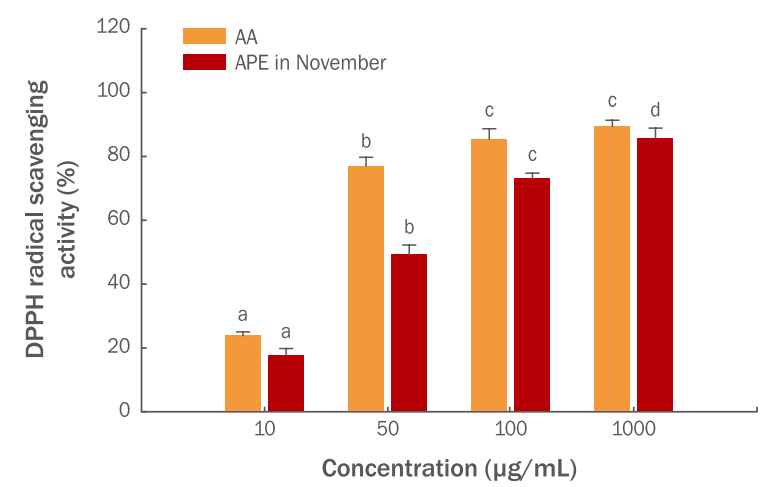

Figure 4. DPPH radical scavenging activity of AA and APE in November according to concentration.

DPPH radical scavenging activity of AA and APE was measured at concentrations of $10,50,100$, and $1000 \mu \mathrm{g} / \mathrm{mL}$. AA was used as a positive control. The activity of APE and AA increased in a concentration-dependent manner. The results are expressed as mean \pm standard deviation from three independent experiments. Different letters (AA, ${ }^{\text {a-c; }}$ APE, ${ }^{a-d}$ ) indicate significant difference $(p<0.05)$. APE, Acer palmatum extract; AA, ascorbic acid; DPPH, 2,2-diphenyl-1-picrylhydrazyl.

$\mathrm{APE}$ 의 시기별, 농도별 항균 활성을 비교하였다. 준비된 평판 배 지 위에 각각의 배양액을 멸균된 면봉으로 고루 접종하고, 멸균된 paper disk에 시료 약 $40 \mu \mathrm{L}$ 를 처리하여 배지 중앙에 올려놓은 다음 $30^{\circ} \mathrm{C}$ 에서 $S$. aureus와 B. subtilis, 그리고 P. aeruginosa 를 $18 \mathrm{~h}$ 배양하여 형성된 clear zone을 측정하였다.

항균실험의 대조군은 메탄올 용매를 사용하였으며, 메탄올 용 매를 휘발시키기 위해 상온에서 $1 \mathrm{~h}$ 동안 방치한 후, 배지에 올 리고 $30^{\circ} \mathrm{C}$ 에서 $18 \mathrm{~h}$ 동안 배양한 결과, 형성된 clear zone이 없 는 것을 확인하였다. 실험에 사용한 3 종의 균주는 시기별로 다 른 항균력을 나타내는 것으로 확인되었다. 특히 $S$. aureus와 $B$.

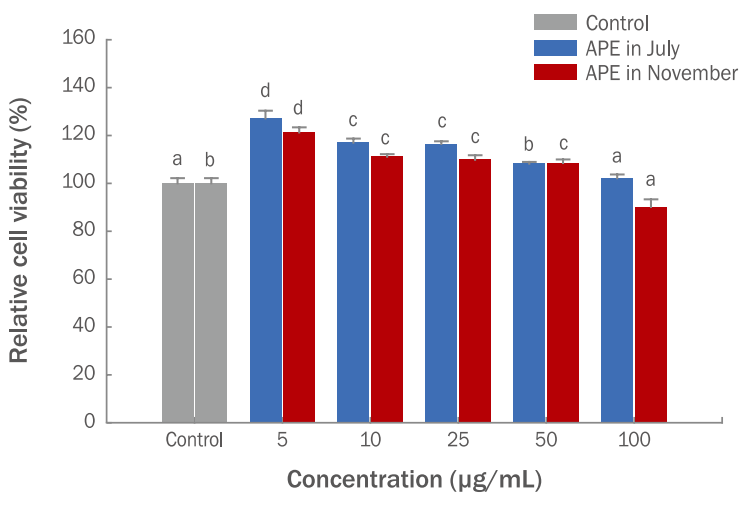

Figure 5. Cell viability of RAW 264.7 cells in APE.

Each cell was treated with $5,10,25,50$, and $100 \mu \mathrm{g} / \mathrm{mL}$ of APE for $48 \mathrm{~h}$. Cell viability of RAW 264.7 cells in APE showed more than $90 \%$ at a concentration of $5-100 \mu \mathrm{g} / \mathrm{mL}$ of APE in July and November. The results are expressed as mean \pm standard deviation from three independent experiments. Different letters ${ }^{\left({ }^{-d}\right)}$ indicate significant difference $(p<0.05)$. APE, Acer palmatum extract.

subtilis는 700, $1000 \mu \mathrm{g} / \mathrm{mL}$ 농도에서 4월부터 11월까지 시기별 로 모두 항균 활성을 나타냈다. S. aureus의 경우, $\mathrm{APE}$ 의 1000 $\mu \mathrm{g} / \mathrm{mL}$ 농도에서 5,6 월에 최대 $13 \mathrm{~mm}$ 의 clear zone을 형성하 였으며, B. subtilis에 대해서는 동일한 농도에서 7,8 월에 최대 $9 \mathrm{~mm}$ 의 clear zone을 형성하였다. P. aeruginosa는 $700 \mu \mathrm{g} /$ $\mathrm{mL}$ 에서는 항균 활성이 나타나지 않았고, $1000 \mu \mathrm{g} / \mathrm{mL}$ 농도에서 6-8월과 11월에만 $8 \mathrm{~mm}$ 의 clear zone을 나타내어 다른 균주에 비해 낮은 항균력을 나타내었다(Table 1).

식물 성장에 관련된 과정은 계절 변화에 따라 달라진다. 사철쑥 의 수확시기별 항균 활성을 측정한 결과, $S$. aureus와 B. subtilis 는 8월에 항균성이 높았지만, P. aeruginosa는 7월에 높은 항 균력을 나타냈다. 이러한 결과는 식물의 생리활성 성분의 생성

Table 1. Anti-bacterial effect of APE using the paper disc method from April to November

\begin{tabular}{|c|c|c|c|c|c|c|c|c|c|}
\hline Sample & Strains & April & May & June & July & August & September & October & November \\
\hline \multirow{3}{*}{$\begin{array}{l}\text { Control } \\
\text { (Methanol) }\end{array}$} & S. aureus & ND & ND & ND & ND & ND & ND & ND & ND \\
\hline & B. subtilis & ND & ND & ND & ND & ND & ND & ND & ND \\
\hline & P. aeruginosa & ND & ND & ND & ND & ND & ND & ND & ND \\
\hline \multirow{3}{*}{$\begin{array}{l}\text { APE } \\
700 \mu \mathrm{g} / \mathrm{mL}\end{array}$} & S. aureus & 8 & 11 & 12 & 10 & 8 & 9 & 7 & 9 \\
\hline & B. subtilis & 8 & 7 & 8 & 8 & 8 & 8 & 7 & 7 \\
\hline & P. aeruginosa & ND & ND & ND & ND & ND & ND & ND & ND \\
\hline \multirow{3}{*}{$\begin{array}{l}\text { APE } \\
1000 \mu \mathrm{g} / \mathrm{mL}\end{array}$} & S. aureus & 8 & 13 & 13 & 12 & 9 & 9 & 8 & 10 \\
\hline & B. subtilis & 8 & 7 & 8 & 9 & 9 & 8 & 8 & 8 \\
\hline & P. aeruginosa & ND & ND & 8 & 8 & 8 & ND & ND & 8 \\
\hline
\end{tabular}

APE, Acer palmatum extract; $S$. aureus, Staphylococcus aureus; B. subtilis, Bacillus subtilis; P. aeruginosa, Pseudomonas aeruginosa; ND, not detected. 
과 함량이 시기적으로 다르기 때문으로 추정된다(Choi et al., $2009 b$ ). 따라서 단풍나무 추출물의 항균성은 다양한 물질에 의 해 나타나는 것으로 생각되며, 항균 활성을 가진 성분이 시기별로 다르게 발현된 것으로 생각된다. 또한 그람 음성균보다 그람 양 성균에서 항균 활성이 높게 나타난 것은 그람 양성균의 세포벽은 peptidoglycan이 표면에 노출되어 항균 활성 물질의 공격을 받기 쉽지만, 그람 음성균은 lipopolysaccharide를 주성분으로 하는 외 막이 peptidoglycan을 보호하는 작용을 하기 때문인 것으로 사료 된다(Nakamura et al., 1991).

\section{Conclusion}

수확시기별 $\mathrm{APE}$ 의 항산화 효과와 항균 활성에 미치는 영향을 객관적으로 검증한 결과는 다음과 같다.

첫째, $\mathrm{APE}$ 의 총 폴리페놀 및 플라보노이드 함량 측정 결과, 7 월과 11 월의 총 폴리페놀 함량은 각각 $173.32 \pm 5.67,191.86 \pm$ $5.32 \mu \mathrm{g} / \mathrm{mg}$ 으로 나타났으며, 총 플라보노이드 함량은 7 월과 11 월에 각각 $51.71 \pm 2.10,44.15 \pm 1.65 \mu \mathrm{g} / \mathrm{mg}$ 으로 나타나 수확 시기별로 함량이 변하고 있음을 확인할 수 있었다(Figure 1, 2).

둘째, $\mathrm{APE}$ 의 항산화 활성 측정결과 $125 \mu \mathrm{g} / \mathrm{mL}$ 농도에서 7 월과 11 월에 각각 $79.81 \%, 81.46 \%$ 의 항산화능을 나타내었고, $\mathrm{APE}$ 에 대한 $\mathrm{DPPH}$ radical 소거능은 농도의존적으로 증가하였다 (Figure 3, 4).

셋째, $\mathrm{APE}$ 의 RAW 264.7 세포에 대한 독성은 대조군에 비하여 $100 \mu \mathrm{g} / \mathrm{mL}$ 에서 $90 \%$ 이상의 세포 생존율을 나타내어 안전한 것 으로 확인되었다(Figure 5).

넷째, $\mathrm{APE}$ 의 항균 활성을 측정결과, $S$. aureus와 B. subtilis 는 $700,1000 \mu \mathrm{g} / \mathrm{mL}$ 농도에서 수확시기별로 모두 항균 활성을 나타냈으며, P. aeruginosa는 $700 \mu \mathrm{g} / \mathrm{mL}$ 에서는 항균 활성이 나 타나지 않았다. $\mathrm{APE}$ 의 $1000 \mu \mathrm{g} / \mathrm{mL}$ 농도에서 $S$, aureus는 5, 6 월에 최대 $13 \mathrm{~mm}, B$. subtilis는 7, 8월에 최대 $9 \mathrm{~mm}$ 의 clear zone을 형성하였으며, P. aeruginosa는 6-8월과 11월에만 8 $\mathrm{mm}$ 의 clear zone을 나타내어 다른 균주에 비해 낮은 항균 활성 을 나타내었다(Table 1).

이러한 결과들을 토대로 단풍나무 추출물의 항산화 활성과 항 균 활성이 일정한 농도로 존재하지 않고 수확시기에 따라 함량이 변하고 있음을 확인하였다. 즉, 단풍나무 추출물은 여름철에 활 발한 광합성의 대사과정에서 ascorbic acid 농도와 superoxide dismutase 활성이 증가하여 항산화능이 높아진 것으로 판단되 며(Lepeduš et al., 2011), 11월에는 단풍나무의 잎에 축적된 당 이 안토시아닌의 원료가 되어 항산화능이 높아진 것으로 사료된 다(Lee \& Moon, 2005). 이에 단풍나무 추출물을 천연 항산화제
로 활용할 경우 수확시기는 중요한 요소로 작용할 것임을 확인하 였고, 향후 수확시기별 이화학적 특성 및 생리활성 성분의 변화에 대한 메커니즘 연구의 필요성을 제언한다.

\section{Author's contribution}

YWS as first author designed and performed an experiment regarding this manuscript. Additionally, YWS wrote it. MJC supported all experiments including sample collection, analysis of anti-oxidant and anti-bacterial activity, and extraction from maple leaves. YKC, HS, and SYS assisted with experimental design and analyzed some correlation with statistics program. JY and KJK revised and reviewed this manuscript. HJK as corresponding author reviewed overall sections and experiments in this manuscript. All authors read and approved the final version of manuscript.

\section{Author details}

Young Whan Sung (Graduated student), Department of Biological Engineering, Konkuk University, 120 Neungdong-ro, Gwangjin-gu, Seoul 05029, Korea; Min Ju Chang (Graduated student), Department of Biological Engineering, Konkuk University, 120 Neungdong-ro, Gwangjin-gu, Seoul 05029, Korea; Yong-Keun Choi (Research Professor), Department of Biological Engineering, Konkuk University, 120 Neungdong-ro, Gwangjin-gu, Seoul 05029, Korea; Hakjin Song (Graduated student), Department of Biological Engineering, Konkuk University, 120 Neungdong-ro, Gwangjin-gu, Seoul 05029, Korea; Sok Young Shim (Graduated student), Department of Biological Engineering, Konkuk University, 120 Neungdongro, Gwangjin-gu, Seoul 05029, Korea; Jae-Yoon Yoon (Graduated student), Department of Biological Engineering, Konkuk University, 120 Neungdong-ro, Gwangjin-gu, Seoul 05029, Korea; Kwang Jin Kim (Senior Researcher), Urban Agriculture Research Division, National Institute of Horicultural and Herbal Science, Rural Development Administration, Wanju-gun, Jeollabuk-do, 55365, Korea; Hyung Joo Kim (Professor), Department of Biological Engineering, Konkuk University, 120 Neungdong-ro, Gwangjin-gu, Seoul 05029, Korea. 


\section{References}

Aritomi M. Chemical constituents in aceraceous plants: I. Flavonoid constituents in the leaves of Acer palmatum Thunberg. Yakugaku Zasshi, 83: 737-740, 1963.

Ball DW. The chemical composition of maple syrup. Journal of Chemical Education, 84: 1647-1649, 2007.

Bi W, Gao Y, Shen J, He C, Liu H, Peng Y, Zhang C, Xiao P. Traditional uses, phytochemistry, and pharmacology of the genus Acer (maple): a review. Journal of Ethnopharmacology, 189: 31-60, 2016.

Blois MS. Antioxidant determinations by the use of a stable free radical. Nature, 181: 1199-1200, 1958.

Borenfreund E, Puerner JA. Toxicity determined in vitro by morphological alterations and neutral red absorption. Toxicology Letters, 24: 119-124, 1985.

Choi JE, Li X, Han YH, Lee KT. Changes of saponin contents of leaves, stems and flower-buds of Panax ginseng C. A. Meyer by harvesting days. Korean Journal of Medicinal Crop Science, 17: 251-256, 2009a.

Choi SR, You DH, Kim JY, Park CB, Kim DH, Ryu J, Choi DG, Park HM. Antimicrobial activity of methanol extracts from Cudrania tricuspidata Bureau according to the parts harvested and time. Korean Journal of Medicinal Crop Science, 17: 335-340, 2009b.

Ding Y, Liang C, Kim JH, Lee YM, Hyun JH, Kang HK, Kim JA, Min BS, Kim YH. Triterpene compounds isolated from Acer mandshuricum and their anti-inflammatory activity. Bioorganic \& Medicinal Chemistry Letters, 20: 15281531, 2010.

González-Sarrias A, Li L, Seeram NP. Effects of maple (Acer) plant part extracts on proliferation, apoptosis and cell cycle arrest of human tumorigenic and non-tumorigenic colon cells. Phytotherapy Research, 26: 995-1002, 2012.

Kang JY, Kim SJ, Park S. Changes in antioxidants of several plant leaves during growth. Journal of Life Science, 14: 104-109, 2004.

Kim JH, Lee BC, Kim JH, Sim GS, Lee DH, Lee KE, Yun YP, Pyo HB. The isolation and antioxidative effects of vitexin from Acer palmatum. Archives of Pharmacal Research, 28: 195-202, 2005.

Kim KS, Han SH, An IS, Ahn KJ. Protective effects of ellagic acid against UVA-induced oxidative stress in human dermal papilla. Asian Journal of Beauty \& Cosmetology, 14: 191-200, 2016.

Kim MJ, Kim JS, Kim KE, Shin KH, Heo K, Cho DH, Park $\mathrm{CH}, \mathrm{Yu} \mathrm{CY}$. Comparison of antioxidative activities from different organs of Rosa rugosa Thunb. Korean Journal of Medicinal Crop Science, 9: 40-44, 2001.

Kim SS, Hyun CG, Lee J, Lim J, Kim JY, Park D. In vitro screening of Jeju medicinal plants for cosmeceutical materials. Applied Biological Chemistry, 50: 215-220, 2007.

Lee SP, Moon JD. Dyeability and antibacterial activities of maple leaves extracts. Journal of Korea Society of Color Studies, 19: 13-19, 2005.

Lepeduš H, Gaća V, Viljevac M, Kovač S, Fulgosi H, Simić D, Jurković V, Cesar V. Changes in photosynthetic performance and antioxidative strategies during maturation of Norway maple (Acer platanoides L.) leaves. Plant Physiology and Biochemistry, 49: 368-376, 2011.

Lim DO. Anatomical aspects in the stem of Korean aceraceous plant. Journal of the Industrial Technology, 4: 247-252, 1997.

Moreno MI, Isla MI, Sampietro AR, Vattuone MA. Comparison of the free radical-scavenging activity of propolis from several regions of Argentina. Journal of Ethnopharmacology, 71: 109-114, 2000.

Nakamura S, Kato A, Kobayashi K. New antimicrobial characteristics of lysozyme-dextran conjugate. Journal of Agricultural and Food Chemistry, 39: 647-650, 1991.

Oh KJ, Kim MJ, Han JS, Ji EH, Kim AJ. Comparative biological properties of Prunus davidiana fruits according to harvest month. The Korean Journal of Food and Nutrition, 28: 643-649, 2015.

Park CS. Antioxidative and nitrite scavenging abilities of medicinal plant extracts. Korean Journal of Food Preservation, 12: 631-636, 2005.

Park JC, Kim SH. Seasonal variation of flavonoid contents in the leaves of Cedrela sinensis. Journal of the Korean Society of Food Science and Nutrition, 24: 578-581, 1995.

Prihantini Al, Tachibana S, Itoh K. Evaluation of antioxidant and $\alpha$-glucosidase inhibitory activities of some subtropical plants. Pakistan Journal of Biological Sciences, 17: 1106-1114, 2014. 
Pyo YH, Lee TC, Logendra L, Rosen RT. Antioxidant activity and phenolic compounds of Swiss chard (Beta vulgaris subspecies cycla) extracts. Food Chemistry, 85: 19-26, 2004.

Schmitzer V, Osterc G, Veberic R, Stampar F. Correlation between chromaticity values and major anthocyanins in seven Acer palmatum Thunb. cultivars. Scientia Horticulturae, 119: 442-446. 2009.

Singleton VL, Rossi JA. Colorimetry of total phenolics with phosphomolybdic-phosphotungstic acid reagents. American Journal of Enology and Viticulture, 16: 144$158,1965$.
Webb DP, Agnihotri VP. Presence of a fungal inhibitor in the pericarps of Acer saccharum fruits. Canadian Journal of Botany, 48: 2109-2116, 1970.

Yim SH, Cho KS, Choi JH, Lee JH, Kim MS, Lee BHN. Effect of various pear cultivars at different fruit development stages on antioxidant and whitening activities. Korean Journal of Food Science and Technology, 48: 59-65, 2016.

Yoon SY, Kim SJ, Sim SJ, Lee HJ. Development of quantitative analytical method for isoflavonoid compounds from fruits of Cudrania tricuspidata. Journal of the Korean Wood Science and Technology, 44: 337-349, 2016. 


\section{국문초록}

\section{수확시기별 단풍나무 추출물의 항산화 활성과 항균 활성}

성영환 ${ }^{1}$ 장민주 ${ }^{1}$ 최용근 ${ }^{1}$, 송학진 ${ }^{1}$, 심석영 ${ }^{1}$, 윤재윤 $^{1}$, 김광진 $^{2}$, 김형주 ${ }^{1 *}$

${ }^{1}$ 건국대학교 생물공학과, 서울, 한국

${ }^{2}$ 농촌진흥청 국립원예특작과학원 도시농업과, 전라북도 완주군, 한국

목적: 본 연구는 수확시기별 단풍나무 추출물의 항산화 활성과 항균 활성을 비교하여, 생리활성이 높은 적정 수확시기 및 이용시기 를 도출하고자 하였다. 방법: 단풍나무 잎을 수확 시기별로 추출한 후, 총 폴리페놀 함량, 총 플라보노이드 함량, DPPH radical 소거 활성, 세포독성, 그리고 Staphylococcus aureus, Bacillus subtilis 그리고 Pseudomonas aeruginosa에 대해 항균 활성을 측정하였다. 결과: 단풍나무 추출물의 항산화 함량과 항산화 활성은 7월과 11 월에 가장 높게 나타났다. RAW 264.7 세포에 대해서 7월과 11월 의 시료 5-100 $\mu \mathrm{g} / \mathrm{mL}$ 농도에서 높은 세포생존율을 나타냈다. 3종의 균주에 대한 항균 실험 결과, 시기별로 항균 활성에 차이를 나 타냈다. 결론: 단풍나무 추출물은 항산화 함량, 항산화 활성 및 항균 활성에서 시기별 차이를 보였으며, 항산화능이 높은 7 월과 11 월의 $100 \mu \mathrm{g} / \mathrm{mL}$ 농도에서 높은 세포생존율을 보였다. 따라서 단풍나무 추출물을 천연 항산화제로서 활용할 경우 수확시기는 중요 한 요소로 작용하는 것을 확인할 수 있었으며 7월과 11 월이 최적의 수확 시기임을 확인하였다.

핵심어: 단풍나무, 항산화 활성, 항균 활성, 세포독성, 시기별 변화

\section{참고문헌}

강정렬, 김석중, 박신. 생육시기별 식물 잎의 항산화제 함량 변화. 생명과학회지, 14: 104-109, 2004.

김경숙, 한송희, 안인숙, 안규중. UVA가 유도하는 산화적 스트레스에 Ellagic Acid가 미치는 인간 모유두 세포 보호효과.

아시안뷰티화장품학술지, 14: 191-200, 2016.

김명조, 김주성, 김기은, 신국현, 허권, 조동하, 박철호, 유창연. 해당화의 채취 부위별 항산화 활성 비교. 한국약용작물학 회지, 9: 40-44, 2001.

박종철, 김성환. 계절에 따른 참죽나무잎 Flavonoid 화합물의 변화 분석. 한국식품영양과학회지, 24: 578-581, 1995. 박찬성. 한약재 추출물의 항산화작용 및 아질산염 소거작용. 한국식품저장유통학회지, 12: 631-636, 2005.

오경주, 김민정, 한정순, 지은희, 김애정. 산복사나무 열매의 수확시기별 생리활성물질 함량 비교. 한국식품영양학회지,

28: 643-649, 2015.

윤순영, 김석주, 심수진, 이학주. 꾸지뽕나무 열매 isoflavonoid 화합물에 대한 정량분석법 개발. 목재공학, 44: $337-$ $349,2016$.

이상필, 문종대. 단풍잎 추출물의 염색성 및 항균성. 한국색채학회논문집, 19: 13-19, 2005.

임동욱. 한국산 단풍나무속 식물의 해부학적 특징. 산업기술연구논문집, 4: 247-252, 1997.

임순희, 조광식, 최진호, 이주현, 김명수, 이별하나. 배 품종별 생육 단계에 따른 산화방지 및 미백 효과. 한국식품과학회

지, 48: 59-65, 2016.

최소라, 유동현, 김종엽, 박춘봉, 김대향, 류정, 최동근, 박현미. 수확부위 및 시기에 따른 꾸지뽕나무 메탄올 추출물의 항 균성. 한국약용작물학회지, 17: 335-340, 2009b.

최재을, 이상국, 한용환, 이기택. 인삼 지상부의 채취시기에 따른 사포닌조성 비교. 한국약용작물학회지, 17: 251-256, 2009a. 


\section{中文摘要}

\section{鸡爪槭提取物的抗氧化和抗菌活性具有季节性变化}

成怜煥 ${ }^{1}$, 張敏珠 $^{1}$, 崔龍根 $^{1}$, 宋學進 $^{1}$, 沈錫英 $^{1}$, 尹載鈆 $^{1}$, 金光珍 $^{2}$, 金亨周 $^{1 *}$

建国大学生物工程科, 首尔, 韩国

2农村振兴厅国立园艺特作科学院，全罗北道，完州郡，韩国

目的: 本研究旨在通过抗氧化和抗菌作用来研究 鸡爪槭提取物（Acer palmatum extract, APE）的最佳收集时 间。方法: 我们通过估计总多酚含量, 总黄酮含量, 2,2-diphenyl-1-picrylhydrazyl（DPPH）自由基清除作用 和细胞存活力来确认APE的抗氧化活性。此外, 我们确定了生长期间对金黄色葡萄球菌, 枯草芽孢杆菌和铜绿 假单胞菌的抗菌活性。结果: APE的抗氧化活性在7月和11月达到峰值。RAW 264.7在7月和11月的APE浓度为 5-100 $\mu \mathrm{g} / \mathrm{mL}$ 时, 显示出高细胞活力。抗菌活性的测定结果, 显示了针对三种细菌的APE的季节性变化。结论: 7月和11月, APE的抗氧化和抗菌活性呈季节变化, 细胞活力较高。因此, 考虑到枫叶槭的最佳季节性采收时间 可能是其天然抗氧化剂特性的重要因素，并且确定了最佳采摘时间，尤其是在7月和11月。

关键词: 鸡爪槭，抗氧化活性，抗菌活性，细胞毒性，季节性变化 